\section{Increasing the clinical interpretability of PHQ-9 through equipercentile linking with health utility values by EQ-5D-3L}

In our recent paper, ${ }^{1}$ we presented the results of the equipercentile linking analysis between the Patient Health Questionnaire (PHQ-9) and the Euro-Qol Five Dimentions Three Levels (EQ-5D-3L) in order to increase the clinical interpretability of the PHQ-9 scores and their changes. Our paper was based on the clinical approach to linking that has been applied to various scales in psychiatry. $^{23}$ Drs Franklin and Young made some important comments on our approach and we will try our best to clarify the concerns they raise.

Drs Franklin and Young cite the International Society for Pharmacoeconomics and Outcomes Research (ISPOR) Good Practices for Outcomes Research Task Force Report for studies mapping nonpreference-based measures of health to generic preference-based measures. ${ }^{4}$ This guideline was prepared mainly for mapping exercises 'to inform a specific cost-effectiveness analysis' (p. 19). ${ }^{4}$ Thus, their items are often concerned with the matching between a dataset that allowed mapping and a dataset for economic analysis. However, the purpose of our study was not to perform any specific costeffectiveness analysis.

The ISPOR report recommends regression methods, and many of their reporting items are about the details of the regression models. However, there are good arguments that equipercentile linking is superior to the regression methods for the purpose of scale-alignment, mainly due to regression to the mean inherent in any regression models. ${ }^{5}$ We used the equipercentile linking, a non-parametric approach that makes no distinction between independent or dependent variables for our more general purpose to link PHQ-9 scores with health utility values.

Our model therefore did not adjust for covariates. It is then important to describe the samples on which the linking was performed, as we did in our report: participants of internet cognitive behavioural therapy trials, mainly in their 30 s through $50 \mathrm{~s}$ and predominantly female, without specific physical comorbidities. Their baseline depression severity ranged equally through subthreshold, mild, moderate and severe depression.

We agree with Drs Franklin and Young, and undoubtedly with many others, that depression is only one aspect of quality of life and that any mapping from only one domain to the whole construct can be misleading. It is appropriate to remember that the correlations between PHQ-9 and EQ-5D-3L were 0.5 at best in our sample and could have been lower if we included more variable samples. Any linking based on such data cannot be strong enough for individual prediction, but must be used judiciously for group-level evaluations. We discussed such limitations in our original publication.

Whether regression models would allow more exact prediction remains an empirical question. By including strong covariates and by improving the conceptual overlap with a preference-based instrument they may, and we agree with Drs Franklin and Young that we need to compare such models with the equipercentile approach, with due attention to the usability of any complex models. In the meanwhile, we hope that our equipercentile linking would contribute to the interpretability of the PHQ-9, one of the most commonly used measures of depression severity, in terms of the more generic health utility values. Toshi A Furukawa $\odot,{ }^{1}$ Stephen Z Levine $\odot{ }^{2}$
Claudia Buntrock, $^{3}$ Pim Cuijpers

${ }^{1}$ Department of Health Promotion and Human Behavior, Kyoto University Graduate School of Medicine / School of Public Health, Kyoto, Japan

${ }^{2}$ Department of Community Mental Health, Faculty of Social Welfare and Health Sciences, University of Haifa, Haifa, Israel

${ }^{3}$ Department of Clinical Psychology and Psychotherapy, Friedrich-Alexander University Erlangen-Nuremberg, Nuremberg, Germany

${ }^{4}$ Department of Clinical, Neuro- and Developmental Psychology, VU University, Amsterdam, Netherlands

Correspondence to Professor Toshi A Furukawa,

Faculty of Medicine, Graduate School of Medicine, Kyoto University, Kyoto, Japan; furukawa@kuhp.kyotou.ac.jp

Twitter Toshi A Furukawa @Toshi_FRKW and Stephen Z Levine @szlevine

Funding The authors have not declared a specific grant for this research from any funding agency in the public, commercial or not-for-profit sectors.
Competing interests None declared.

Patient consent for publication Not required.

Provenance and peer review Not commissioned; internally peer reviewed.

\section{(2) OPEN ACCESS}

Open access This is an open access article distributed in accordance with the Creative Commons Attribution Non Commercial (CC BY-NC 4.0) license, which permits others to distribute, remix, adapt, build upon this work non-commercially, and license their derivative works on different terms, provided the original work is properly cited, appropriate credit is given, any changes made indicated, and the use is non-commercial. See: http:// creativecommons.org/licenses/by-nc/4.0/.

(c) Author(s) (or their employer(s)) 2021. Re-use permitted under CC BY-NC. No commercial re-use. See rights and permissions. Published by BMJ.

\section{Check for updates}

To cite Furukawa TA, Levine SZ, Buntrock C, et al. Evid Based Ment Health 2021;24:e6.

Received 10 July 2021

Accepted 13 July 2021

Published Online First 22 July 2021

\section{(5) Linked}

http://dx.doi.org/10.1136/ebmental-2021-300265

Evid Based Ment Health 2021;24:e6. doi:10.1136/ ebmental-2021-300299

\section{ORCID iDs}

Toshi A Furukawa http://orcid.org/0000-0003-21593776

Stephen Z Levine http://orcid.org/0000-0002-55440420

\section{REFERENCES}

1 Furukawa TA, Levine SZ, Buntrock $C$, et al. How can we estimate QALYs based on PHQ-9 scores? Equipercentile linking analysis of PHQ-9 and EQ-5D. Evid Based Ment Health 2021;24:97-101.

2 Leucht S, Kane JM, Etschel E, et al. Linking the PANSS, BPRS, and CGI: clinical implications. Neuropsychopharmacology 2006:31:2318-25.

3 Furukawa TA, Reijnders M, Kishimoto $S$, et al. Translating the BDI and BDI-II into the HAMD and vice versa with equipercentile linking. Epidemiol Psychiatr Sci 2019:29:1-13.

4 Wailoo AJ, Hernandez-Alava M, Manca A, et al. Mapping to estimate Health-State utility from NonPreference-Based outcome measures: an ISPOR good practices for outcomes research Task force report. Value Health 2017:20:18-27.

5 Fayers PM, Hays RD. Should linking replace regression when mapping from profile-based measures to preference-based measures? Value Health 2014;17:261-5. 